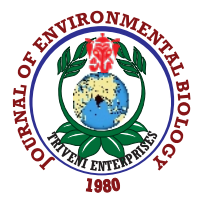

\title{
An insight into the sequential changes in enzymatic activities during retting of jute (Corchorus spp. L.).
}

\author{
B. Majumdar*, A.R. Saha, S. Sarkar, S.K. Sarkar, S.P. Mazumdar, L. Chattopadhyay and S. Barai \\ Division of Crop Production, ICAR-Central Research Institute for Jute \& Allied Fibres, Kolkata-700 120, India \\ ${ }^{*}$ Corresponding Author Email : bmajumdar65@gmail.com
}

\begin{abstract}
Methodology: Two large scale retting trials were conducted with and without microbial retting consortium in triplicate. The retting water samples were collected every day at $24 \mathrm{hrs}$ interval from both the trials. Polygalcturonase (PG), pectin lyase (PNL) and xylanase activities along with the $\mathrm{pH}$ were measured from the collected retting water samples following standard procedure. Fibre quality parameters were also studied from the resultant fibre obtained from both the retting trials.
\end{abstract}

Aim: To study the dynamics of enzymes involved in biochemical process of jute (Corchorus spp.) retting with and without microbial retting consortium.

Results: There was a sharp decrease in $\mathrm{pH}$ of retting liquor by 1.35 units and that of pectin lyase activity by $97.9 \mathrm{Um}^{-1}$ within 24 hrs of inoculation of microbial retting consortium. Thereafter, higher pectin lyase $\left(123.1 \mathrm{Uml}^{-1}\right)$, polygalacturonase $\left(3.56\right.$ luml $\left.^{-1}\right)$ and xylanase $\left(0.818 \mathrm{IUml}^{-1}\right)$ activities were recorded during middle stage of retting. The enzyme activities were lower and non-significant at last stage of retting (11-14 days). The completion of retting without microbial consortium took longer time due to lower enzymatic activities as compared to microbial consortium mediated retting.

Interpretation: The PG, PNL and xylanase enzymes released by the microbial consortium during retting of jute helped in faster biodegradation of pectin and xylan compared to control retting. Hence, the pre retting treatment of jute with microbial consortium is suggested for quick retting.
Dynamics of enzymes during jute retting

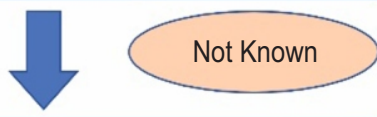

Jute retting trials with and without microbial retting consortium conducted

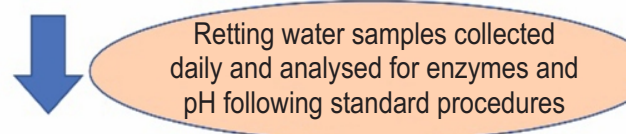

Polygalacturonase, pectin lyase and xylanase activites in retting water fluctuate depending on the availability of substrates and $\mathrm{pH}$ of retting water

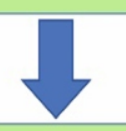

The entire jute retting process could be divided into three stages depending on the change in $\mathrm{pH}$ and dynamics of enzyme activities

Key words: Fibre quality, Jute, Microbial retting, Polygalacturonase

How to cite : Majumdar, B., A.R. Saha, S. Sarkar, S.K. Sarkar, S.P. Mazumdar, L. Chattopadhyay and S. Barai: An insight into the sequential changes in enzymatic activities during retting of jute (Corchorus spp. L.). J. Environ. Biol., 42, 636-643 (2021). 


\section{Introduction}

Jute (Corchorus spp.) is one of the most versatile bast fibre crops, commonly known as golden fibre and widely grown in the South-east Asian countries. The quality of jute fibre largely depends on the process of retting. Retting, a purely biochemical process, is used for releasing fibres from jute stalk. The jute retting process is carried out by enzymes (pectinases, hemicellulases, cellulase and oxidoreductases) produced by an indigenous complex microbial community to degrade cellular tissues, pectins and gums, etc. Among all pectinases, pectin lyases are of particular interest, as they degrade pectin polymers directly by $\beta$-elimination mechanism that results in the formation of 4, 5-unsaturated oligogalacturonides while other pectinases act sequentially to degrade pectin molecule completely (Yadav et al., 2009). Pectin lyase is also highly inducible enzyme even though there are reports of its considerable production in absence of its natural inducer (Piccoli-Valle et al., 2001).

Pre-treatment of low-quality jute fibre with pure and thermo stable xylanase is used for removal of xylan without affecting the fibre strength during the spinning process (Saha, 2000). Few reports are available on the use of xylanase enzyme for desizing and scouring (improving whiteness and absorbence of the textile material) of textile fibres (Csiszar et al., 2001; Losonczi et al., 2005). Use of pectinolytic bacterial inoculum is gaining momentum as a pre-treatment step to obtain fibres from raw bast materials namely jute, flax, hemp and kenaf. It facilitates separation of cellulose fibre bundles from the matrix (Di Candilo et al., 2010; Munshi and Chattoo, 2008; Yu and Yu, 2007) and plays an important role in determining the quality and yield of jute fibre (Ahmed and Akhter 2001). A very efficient microbial consortium capable of producing highly active pectin and xylan degrading enzymes (polygalacturoase, pectin lyase and xylanase) without producing any traces of cellulase had been developed, commercialized, popularized among jute farming community, which can ret jute and mesta very effectively with shorter retting duration and better fibre quality (Das et al., 2015; Das et al., 2018).

Three constituent microbes of consortium (PJRB1, PJRB2 and PJRB3) were identified as three different strains of Bacillus pumilus by metabolic fingerprinting pattern of the isolates using Biolog and by $16 \mathrm{~S}$ rDNA sequencing (ribotyping) of a $977 \mathrm{bp}$ fragment (Das et al., 2015). These three strains of Bacillus pumilus were later identified as Bacillus safensis, Bacillus velezensis and Bacillus altitudinis through whole genome sequencing based taxonomic affiliation of the isolates (Datta et al., 2020). The endospores of microbial consortium showed higher resistance to temperature, $\mathrm{pH}, \mathrm{UV}$ irradiation and antibiotics than their vegetative forms and 18-month-old endospores can ret jute within 10 days with very good quality fibre (Chattopadhyay et al., 2019). Further, the immobilized strain of PJRB1 was found to have $132.6 \%$ higher xylanase production capacity over free cells after $72 \mathrm{hrs}$ of incubation indicating scope of its industrial application for extra cellular xylanase production without any cellulase activity (Kundu and Majumdar, 2018). In conventional retting of jute, increase in EC,
BOD, COD and nutrients contents including cfu of pectin, cellulose, lignin and xylan degraders but with a reduction in $\mathrm{pH}$ were recorded in post-retting water in comparison to pre-retting water (Majumdar et al., 2019). Delignification by using lignin degrading bacteria of Bacillus spp. helped in reduction of lignin content in jute fibre to make it suitable for use in textiles (Barai et al., 2020). Although retting is a crucial biochemical process for the production of fibre bundles, the available reports on bacterial communities associated in jute retting environments are scarce; whereas, most literature are related to flax retting (Donaghy et al., 1990; Ge et al., 2007; Ling et al., 2009). So far, enzymological data was not available to assess the changes during the entire jute retting period. Hence, this study was undertaken to assess the composed actions of enzymes liberated by consortium microbes during entire jute retting period, which would help in understanding the dynamics of jute retting process.

\section{Materials and Methods}

Collection of jute sample: The most popular and extensively cultivated variety of jute (cV. JRO 524) was grown at the agricultural farm of ICAR-Central Research Institute for Jute \& Allied Fibres, Barrackpore (9 m AMSL; $22^{\circ} 45^{\prime} \mathrm{N}, 80^{\circ} 26^{\prime} \mathrm{E}$ ), Kolkata, West Bengal, India by following standard agronomic practices during April to August, 2018. Jute plants were harvested for optimum yield and fibre quality at maturity after 120 days of sowing, the appropriate time of harvesting of jute (Majumdar et al., 2014b).

Microbial retting consortium: Microbial retting consortium consisted of three different strains of Bacillus spp. (PJRB1, PJRB2 and PJRB3) having high polygalacturonase, pectin lyase and xylanse activities but without any cellulase activity with accession numbers MTCC 5573, MTCC 5574 and MTCC 5575 (Das et al., 2015) used for the present study. The microbial retting consortium has been proved beneficial for faster retting of jute with fibre quality improvement in terms of colour, lustre, fibre strength and fibre fineness etc. (Das et al., 2015; Das et al., 2018). The partial sequences of $16 \mathrm{~S}$ rRNAgene and genome sequences of PJRB1, PJRB2 and PJRB3 have been submitted to National Centre for Biotechnology Information (NCBI) with accession number KM091823, KM091824 and KM091825, and VFLO0000000, VFLN00000000 and VFLM00000000 respectively (Das et al., 2015; Datta et al., 2020). All three strains of microbial consortium were submitted for maintenance and preservation to the Microbial Type Culture Collection (MTCC), IMTECH (Institute of Microbial Technology) under Council of Scientific and Industrial Research, Chandigarh, India.

Experimental preparation: The harvested jute plants after leaf shedding were used for retting trial in mid-August, 2018. Five $t$ each of jute plants were placed in number of identical concrete retting tank filled with 50,000 litres of underground water in each tank. The component organisms of microbial retting consortium (MRC) were grown separately in yeast extract pectin broth $(1 \%$ yeast extract, $0.5 \% \mathrm{NaCl}, 1 \%$ pectin, $\mathrm{pH} 7.0$ ) for $48 \mathrm{hrs}$ and mixed 1:2:1 ratio. The inoculum of microbial retting consortium @ 2 I was 
applied in each retting tank. Proportional control of jute fibre bundles were retted without microbial consortium keeping other conditions constant. Both the sets of experiments were replicated thrice following the same procedure. The $\mathrm{pH}$ of water of retting tanks was adjusted to slightly alkaline (7.5) by adding $\mathrm{NaOH}$ for achieving better activity of microbes. After adding inoculum to the water of retting tank at the initiation of retting trial was in the magnitude of $10^{10} \mathrm{cfu} \mathrm{ml}^{-1}$. Underground water was used to eliminate the possibility of presence of other organisms since micro flora present in pipeline water was negligible.

Sampling of retting liquor for analysis: The retting liquor was collected every day (exactly at $24 \mathrm{hrs}$ interval) from replicated retting trials in each $50 \mathrm{ml}$ sterile container and refrigerated at $4^{\circ} \mathrm{C}$ until analyzed for microbiological and enzymological parameters. The water lost due to evaporation was readjusted once during trial adding tap water to maintain the desired water level. The changes in $\mathrm{pH}$ value and temperature of the retting liquor were recorded simultaneously. For analysis, the refrigerated retting liquor sample was kept at least for $2 \mathrm{hrs}$ at room temperature for stabilization. For enzymological analysis, retting liquor was centrifuged at 10,000 rpm for 5 min and used as cell-free enzyme source.

Enzymological analysis: During retting trials, the day wise retting water samples collected were used for enzymatic assays. Polygalacturonase (PG) activity was measured by modified DNS method of Miller (Phutela et al., 2005). PG activity was expressed in IU that corresponds to the amount of $\mu \mathrm{M}$ of galacturonic acid released $\mathrm{min}^{-1} \mathrm{ml}^{-1}$ of culture supernatant keeping D-galacturonic acid as the calibration standard. Pectin lyase (PNL) activity was determined by the modified thiobarbituric acid method of Nedjma et al. (2001). The amount of enzyme required to change the absorbance of 0.01 under the assay condition was defined as 1 Unit of PNL activity. Xylanase activity was measured by reducing sugar estimation method using 3, 5 Dinitro salicylic acid (Monisha et al., 2009). One unit of xylanase activity (IU) corresponds to I mol of xylose $\mathrm{min}^{-1} \mathrm{ml}^{-1}$ of cell-free culture supernatant.

Assessment of fibre quality: After completion of retting in the trials, fibre was extracted manually, washed in clean water, airdried and fibre bundle strength was measured as described by Roy et al. (2009) using electronic fibre bundle strength tester and fibre fineness by airflow fineness method of Bandopadhyay and Sinha (1968) as per technical specification of Indian Standards Institute (ISI). The lustre is a characteristic of shine (the fibre giving more shine in the light is having better lustre) was recorded by visual observation of fibre in the sunlight. The hardy, undecomposed barky region at the basal or lower end of the jute fibre is called root. The root content in terms of weight percentage was recorded by the method of Roy and Saha (2013). Colour is the visual property of a fibre, which distinguishes its appearance as golden, redness, yellowness, greyness etc. The colour of the dried fibre was recorded by naked eye visual observation.

Statistical analysis: The data were analyzed with Sigma plot 11.0 for calculating standard deviation.

\section{Results and Discussion}

The $\mathrm{pH}$ of retting water (Fig. 1a) decreased with microbial retting consortium immediately within 24 hrs of the initiation of retting experiment. This decreasing trend was maintained up to $48 \mathrm{hrs}$ and the $\mathrm{pH}$ value reached minimum (6.15). After 48 hours, a slight increase in the $\mathrm{pH}$ values was observed. During mid-stage of retting period, the $\mathrm{pH}$ of retting water was in the range of 6.40 at day 3 to 6.76 at day 9 . At the last stage of retting (10-14 days), the $\mathrm{pH}$ of the retting water reached between a narrow range of 6.75 and 6.80 . The component microbes of retting consortium act efficiently within a wide range of $\mathrm{pH}$ values. It was evident from Fig. 1a, that the retting water becomes slightly acidic with initiation of jute retting, but further change in $\mathrm{pH}$ with progress of retting was very slow until the last stage of retting period, when it reached near neutral.

At initial stage of retting, a sharp decrease in the $\mathrm{pH}$ of retting water might have resulted from release of organic acids namely butyric acid, acetic and lactic acid during microbial metabolism of sugars, pectins and other gummy materials (Das et al., 2011; Majumdar et al., 2019). The stability in pH of retting water from day 10 to day 14 of retting was related to negligible release of organic acids due to lack of degradable substrates, which has helped in the stabilization of $\mathrm{pH}$ of retting liquor. The ambient temperature was also recorded throughout the retting trial; the maximum temperature ranged from 27.7 to $35.8^{\circ} \mathrm{C}$ with a mean of $31.9^{\circ} \mathrm{C}$ whereas the minimum temperature ranged from 24.7 to $27.4^{\circ} \mathrm{C}$ with a mean of $25.9^{\circ} \mathrm{C}$. The pectin lyase activity recorded a sharp decrease by $97.9 \mathrm{U} \mathrm{ml}^{-1}$ of retting water on the very second day of retting trial with microbial retting consortium (Fig. 1b). The highest amount of pectin lyase activity $\left(123 \mathrm{U} \mathrm{ml}^{-}\right.$ $\left.{ }^{1}\right)$ was recorded on $3^{\text {rd }}$ day and thereafter a gradually decreasing trend was observed till day 6 of retting $\left(34.9 \mathrm{U} \mathrm{ml}^{-1}\right)$. However, a slight increase in pectin lyase activity was also recorded from day $7\left(59 \mathrm{U} \mathrm{ml}^{-1}\right)$ to day $8\left(77.3 \mathrm{U} \mathrm{ml}^{-1}\right)$ during the middle stage of retting period. At last stage of retting, a decreasing trend in pectin lyase activity was noted, and it recorded only $17 \mathrm{U} \mathrm{ml}^{-1}$ of retting liquor on the completion of retting (day 14).

This signifies that pectin lyase degrades pectin to its simpler form polygalacturonic acid and then polygalacturonase acts on it to release reducing sugars. The assessment of dynamics of polygalacturonase (Fig.1c) enzyme secreted by the component microbes of retting consortium during the entire retting period revealed that polygalacturonase activity decreased on day 2 by $0.51 \mathrm{U} \mathrm{ml}^{-1}$ of retting water. The maximum polygalacturonase activity was observed during the middle stage of retting period (day 3 to day 9 ) and the maximum activity was recorded on day 7 (3.56 IU ml-1) of retting. During the last stage of retting (10-14 days), the polygalacturonase activity was reduced from $2.97 \mathrm{IU} \mathrm{ml}^{-1}$ of retting water to $2.60 \mathrm{IU} \mathrm{ml}^{-1}$ of retting water on the completion of retting. The dynamics of polygalacturonase activity of the consortium microbes on jute bast was quite similar to the dynamics of reducing sugar estimated during water-retting process of hemp by aerobic strain Bacillus sp. ROO40B reported 

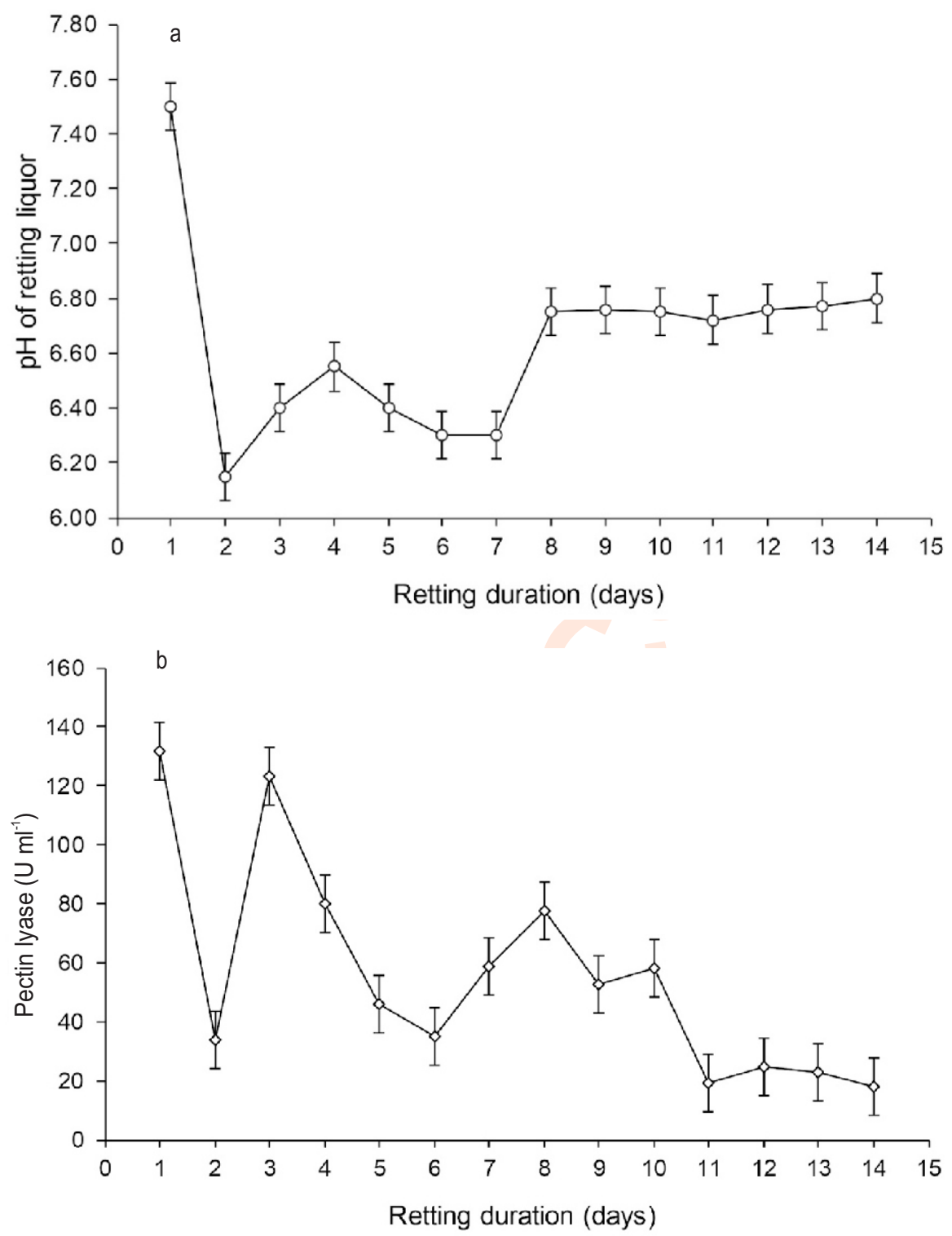

Fig. 1: Changes observed during retting of jute (Corchorus spp.) with microbial consortium (a) pH of retting liquor and (b) pectin lyase activity.

by Di Candilo et al. (2010). All three Bacillus strains of microbial retting consortium are xylanase producers. The dynamics of xylanase production during retting period is immensely important for bio scouring and bio-bleaching of jute fibre. At initial stage of jute retting, a sharp decrease in xylanase activity by $0.055 \mathrm{IU} \mathrm{ml}^{-1}$ of retting water was observed on day 2 from the initiation of retting trial (Fig. 1d) like pectin lyase and polygalacturonse activities. Further, a steady increase in xylanase activity was observed during mid-stage of retting period with a maximum activity of $0.818 \mathrm{IU} \mathrm{m}^{-1}$ on day 7 . This indicated the fact that xylan was exposed for degradation with gradual removal of pectin layer by pectinolytic enzymes as xylan was covered by pectin containing materials in jute stem. At the end of retting period, the xylanase activity was maintained to the level of initial status. Jute retting with microbial consortium was completed in 14 days (Table 1) whereas it took 22 days without microbial consortium.

The use of microbial consortium having very high potential of enzymatic activities (polygalacturonase, pectin lyase and xylanase) helped in faster retting of jute as represented in Fig. $1 \mathrm{~b}, \mathrm{c}, \mathrm{d}$ as compared to the retting without microbial consortium characterized by lower enzymatic activity (Fig. 2). The quick retting of jute with microbial consortium also helped in recovery of full length of fibre, thus enhancing the recovery of fiber by $10.9 \%$ 

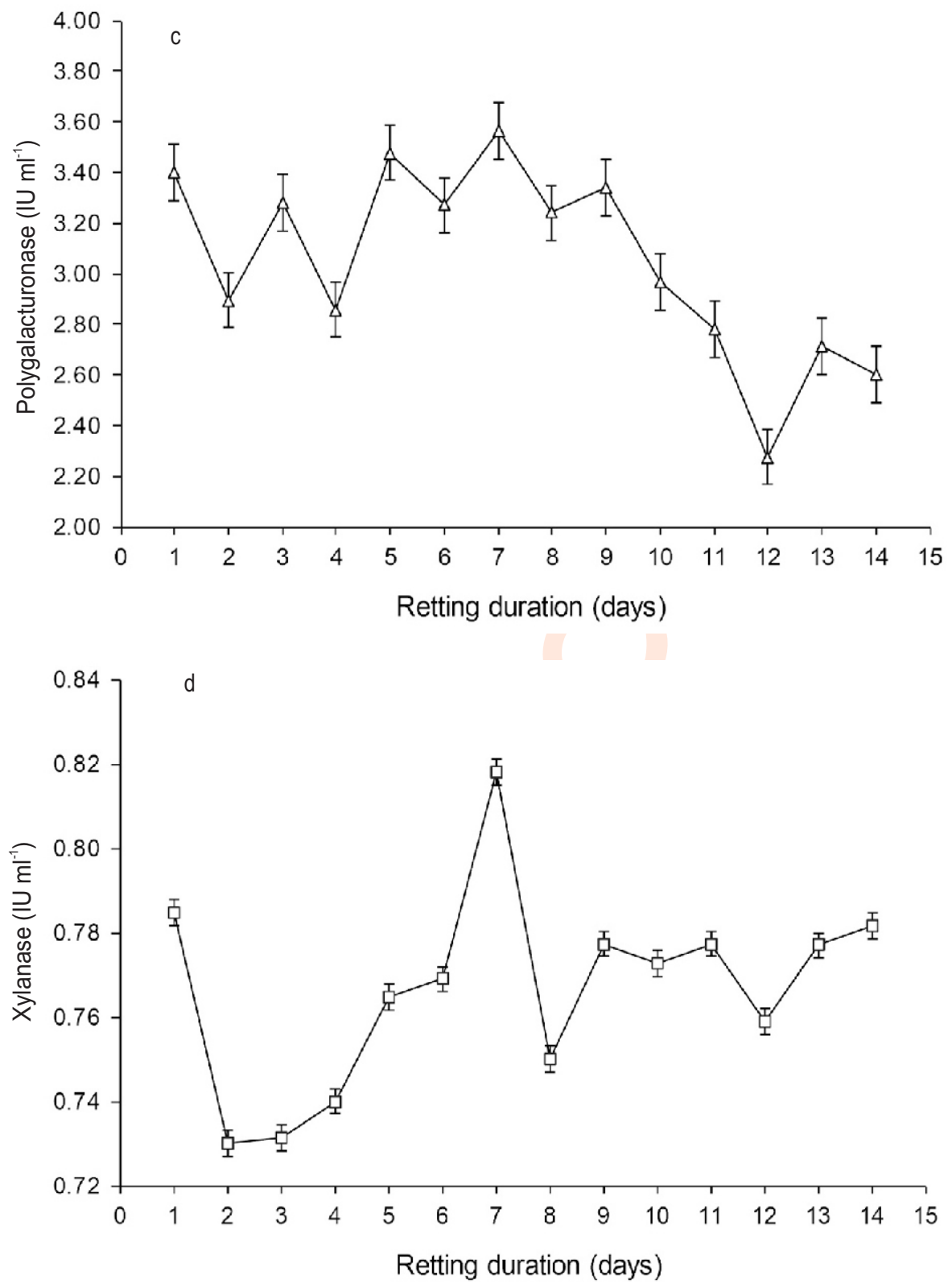

Fig. 1: Changes observed during retting of jute (Corchorus spp.) with microbial consortium (c) polygalacturonase activity and (d) xylanase activity.

(Table 1) as compared to the fibre recovery in retting without microbial consortium. Jute plants have less complex structure of pectin at top portion of the stem whereas middle to bottom portion of the plants have highly methyl esterified pectin, so lesser time is required for bio-degradation of top portion of the stem than their mid and basal portion (Das et al., 2018). In this study, under conventional retting, it took longer retting duration for completion of retting, which resulted in loss of top portion of fibre hence lower fibre recovery was obtained under conventional retting. The fibre produced from microbial consortium use had higher fibre strength and fineness as compared to the fibre obtained from the control. This was due to proper and uniform retting which was evident from the lower root content data (Table 1). The jute fibre obtained using microbial consortium had very less root content $(2.5 \%)$ compared to the fibre produced from control $(16 \%)$ which indicates improper retting in control, i.e., conventional method of retting. High root content in jute fibre produced from conventional retting implies that undecomposed materials were present in larger quantity which is not desirable for quality fibre. Similar increase in fibre recovery, fibre strength along with better fineness 


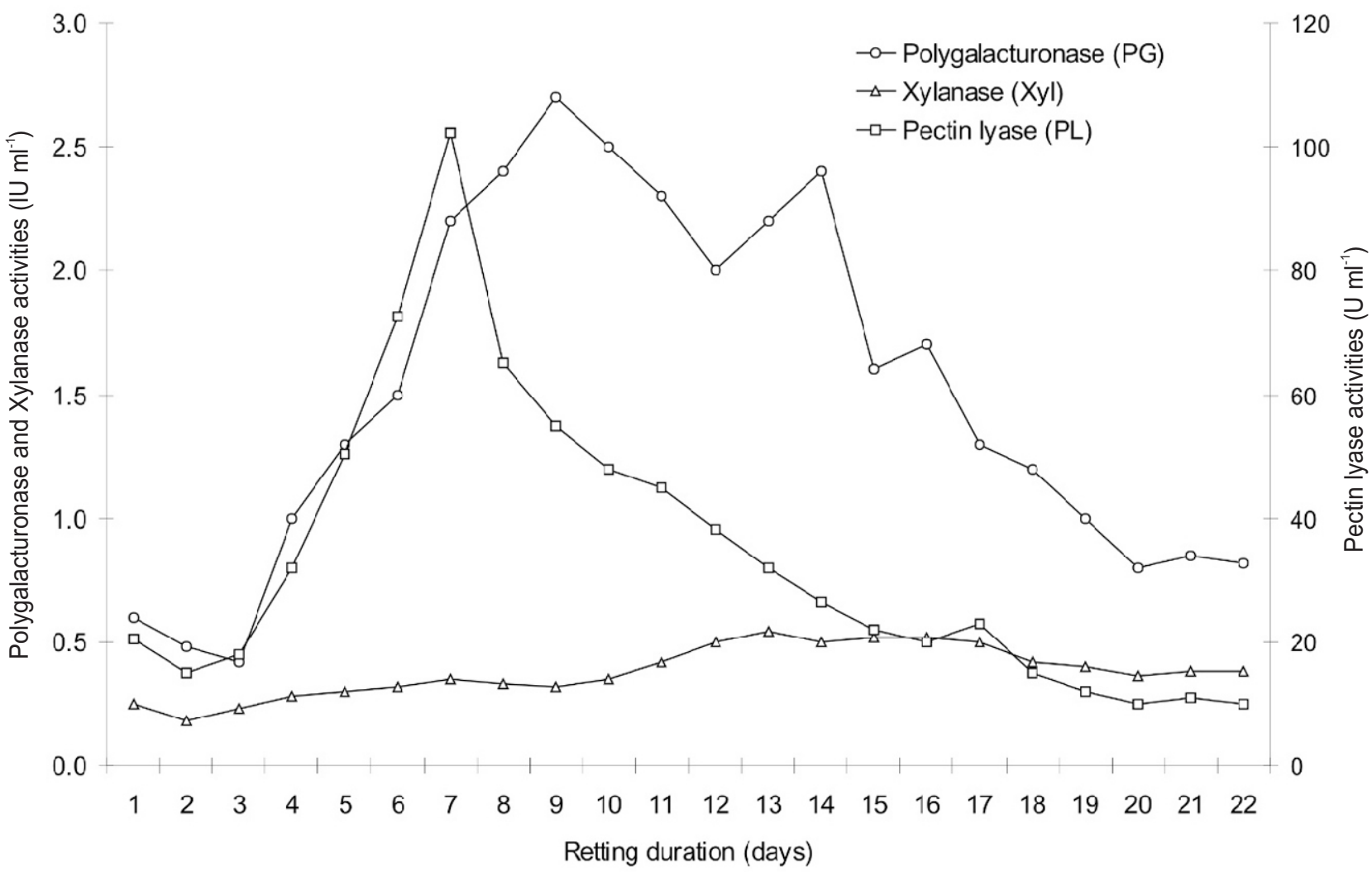

Fig. 2: Changes observed in enzymatic activities during conventional retting of jute (Corchorus spp.).

Table 1: Comparative assessment of jute retting with and without microbial consortium on retting duration, fibre recovery and quality

\begin{tabular}{llll}
\hline Quality parameters & Retting with microbial consortium & Retting without microbial consortium & $\mathbf{C D}(\mathbf{P}=\mathbf{0 . 0 5})$ \\
\hline Retting duration (days) & 14 & 22 & 2.30 \\
Fibre recovery $\left(\mathrm{q}\right.$ ha $\left.^{-1}\right)$ & 28.5 & 25.7 & 1.85 \\
Fibre strength $\left(\mathrm{g} \mathrm{tex}^{-1}\right)$ & 25.8 & 21.2 & 1.65 \\
Fibre fineness (tex) & 2.86 & 3.18 & 0.22 \\
Fibre colour & Golden & Greyish & - \\
Root content $(\%)$ & 2.5 & 16 & - \\
Lustre & Bright and shining & Dull & - \\
\hline
\end{tabular}

and lower retting duration using same microbial consortium has been reported earlier (Majumdar et al., 2014a; Das et al., 2018). The bleaching action of component microbes of microbial consortium assisted in the recovery of lustrous fibre with golden colour which was not feasible from the control trial (Das et al., 2018). In this study, the dynamics of various enzymes involved in jute retting during the entire jute retting process with and without a pectinolytic bacterial consortium were investigated.

The consortium consisting of three bacterial strains of Bacillus spp. had novel characteristics of producing pectinolytic enzymes (polygalacturonase and pectin lyase) as well as xylanase. At the same time, these three Bacillus strains did not produce even traces of cellulases. The results demonstrated the fact that the bacterial inoculums substantially influenced the retting process resulting better fibre recovery and enhanced fibre quality. We summarized the observed morphological modification, dynamics of $\mathrm{pH}$ and various enzymes related to them during the entire jute retting process to three sequential retting stages: Stage 1: Initial retting stage (1-2 days); Stage 2: Middle retting stage (3-9 days); and Stage 3: Final retting stage (10-14 days). The initial stage of retting was characterized by separation of fibrous components from other bast tissues, mainly due to pectinolytic dissolution of middle lamellas joining cells with non-lignified wall, facing intercellular spaces. Release of organic acids and sugars 
lowered the $\mathrm{pH}$ level of the medium as observed within $24 \mathrm{hrs}$ of inoculation (Fig. 1a) because jute plants after absorbing water swell and burst at several places on the stem and release sugars, glucosides and nitrogenous compounds, which upon decomposition release several organic acids (Ali 1958; Ali and Islam1963; Ali et al., 1976). The average pH was lowered by 1.35 units. The immediate response of retting microbes at low $\mathrm{pH}$ level was observed by lowering of the enzyme activities. Nearly $100 \mathrm{U}$ $\mathrm{ml}^{-1}$ pectin lyase activity was lost within $24 \mathrm{hrs}$.

The polygalacturonase and xylanase enzyme activities followed the similar trend. Ahmed and Akhter (2001) reported continuous change in chemical composition and $\mathrm{pH}$ of retting liquor because of various bio-chemical reactions occurring during retting process. So, this preliminary stage can be defined as the decrease of $\mathrm{pH}$ as well as reduction of enzyme secretion due to non-availability of their respective substrates, since all three enzymes are inducible in nature. In middle stage of retting, after the detachment of surrounding tissues, fibre bundles were directly subjected to enzymatic attack. After the release of organic acids and other compounds, pectin, has between fibre cells becomes accessible to the retting microbes. Polygalacturonase (Zhang et al., 2000; Tamburini et al., 2003) and pectinlyase, the most significant pectin depolymerising enzyme, plays a crucial role in jute retting process (Soriano et al., 2005). A rapid increase in pectin lyase activity was observed with the highest value scored on day $3\left(123.1 \mathrm{U} \mathrm{ml}^{-1}\right)$, followed by a decrease with a minimum value on day $6\left(34.9 \mathrm{U} \mathrm{ml}^{-1}\right)$. This was due to the fact that the inducible enzyme pectin lyase acts depending on the accessibility and availability of highly methyl-esterified pectin. It reaches minimum level as soon as pectin gets depleted.

Another increase in pectin lyase activity was observed with a lesser peak value $\left(77 \mathrm{U} \mathrm{m}^{-1}\right)$ on day 8 . Since middle lamellas joining the fibres are modified by lignin and generally composed of less methylated pectins (Carpita and Gibeaut 1993), they offer higher resistance and less availability to pectinolytic enzymes, thus retarding pectin lyase activity. After initial decrease at first stage, a steady increasing trend was observed in polygalacturonase activity, reaching highest value on day $7\left(3.56 \mathrm{IU} \mathrm{ml}^{-1}\right)$. This clearly indicates the fact that when more pectin lyase actes upon highly esterified pectins present in the plant tissues, simpler form of pectin, i.e., polygalaturonic acid is released. Polygalacturonase enzyme actes on polygalacturonic acid releasing reducing sugars into the medium, required for the growth of retting microbes. Hemicellulolytic enzymes depolymerize hemicelluloses precipitated on the surface of the fibre. Thus, it increased the access of bleaching chemicals to the lignin layer by opening the pulp structure (Paice et al., 1998).

Xylanases are important form of hemicellulases involved in jute retting process (Gomes et al., 1992), for giving biobleaching or polishing effect to the fibre. Xylanase production dynamics showed that after initial decrease in the primary stage of retting, a steady increasing trend was observed up to day 7 $\left(0.818 \mathrm{IU} \mathrm{m}^{-1}\right)$ and then the activity decreased to a certain level. This was possibly due to the fact that xylan present in the outer core of middle lamella can be made accessible to the retting microbes. As soon as pectin gets degraded, xylan becomes unveiled to the microbes and are attacked for degradation. The combined actions of these three enzymes secreted by the retting consortium helps in quick biodegradation of plant pectins and hemicelluloses, which a has positive impact on the entire retting process. At final stage of retting, the combined action of pectin and xylan degrading enzymes unveils the cellulosic network of fibre cells (Doi and Kosugi, 2004; Han et al., 2004). Since microbial retting consortium was devoid of production of any traces of cellulolytic enzymes, structural polysaccharide remains untouched. Due to unavailability of substrates, the enzyme activity was found in significant.

In case of conventional retting without consortium, similar pattern of retting was noticed, except that enzymatic activities were quite low at each stage compared with retting using microbial consortium. The dynamics and combined action of enzymes liberated by a microbial consortium accelerated the biochemical process of jute retting. Hence, pre-retting treatment of jute plants with pectinolytic microbial consortium is advisable for accelerating the retting process for higher productivity and quality improvement over conventional ways of jute retting.

\section{Acknowledgment}

Authors are highly grateful to the Director, ICAR-Central Research Institute for Jute and Allied Fibres, Barrackpore, Kolkata for providing necessary facilities and financial support for the study.

\section{Add-on Information}

Authors' contribution: B. Majumdar: Conceptualization, supervision, writing, reviewing and editing; A. R. Saha, S. Sarkar and S. K. Sarkar: Data curing, reviewing, editing; S. P. Mazumdar: Methodology and Data curing; L. Chattopadhyay and S. Barai: Methodology

Research content: The research content of manuscript is original and has not been published elsewhere.

Ethical approval: NotApplicable

Conflict of interest: The authors declare that there is no conflict of interest.

\section{Data from other sources: NotApplicable}

Consent to publish: All authors agree to publish the paper in Journal of Environmental Biology.

\section{References}

Ahmed, Z. and F. Akhter: Jute retting: An overview. Online J. Biol. Sci., 1, 685-688 (2001). 
Ali, M.M. and A. Islam: Pectin enzymes of Penicillium frequentans involved in the retting of jute. Pakistan J. Sci. Indust. Res., 8, 4751 (1963).

Ali, M.M., Alam, M.S., A.K.M. Eshque and A.L. Khondakar: Studies on the mechanization of jute retting. Bangladesh J. Jute Fibre Res., 1, 6170 (1976).

Ali, M. M.: Aerobic bacteria involved in the retting of jute. Appl. Microbiol., 6, 87-89 (1958)

Bandyopadhyay, S.B. and N.G. Sinha: An airflow method for the determination of the fibre fineness of jute and mesta. J. Text. Inst., 59, 148-151 (1968).

Barai, S., L. Chattopadhyay and B. Majumdar: Studies on delignification in jute (Corchorus spp L.) fibre with promising lignin degrading bacterial isolates. J. Environ. Biol., 41, 703-710(2020).

Carpita, N.C. and D.M. Gibeaut: Structural models of primary cell walls in flowering plants: Consistency of molecular structure with the physical properties of walls during growth. Plant J., 3, 1-30 (1993).

Chattopadhyay, L., B. Majumdar, S.P. Mazumdar, A.R. Saha, R. Saha and S. Barai: Use of bacterial endospore with longer shelf-life in improved retting of jute. J. Environ. Biol., 40, 245-251 (2019).

Csiszar, E., K. Urbanskzi and G. Szakaes: Biotreatment of desized cotton fabric by commercial cellulose and xylanase enzymes. J. Mol. Catal., B Enzym., 11, 1065-1072 (2001).

Das, B., S. Tripathi, A. Chakraborty and K. Chakrabarti: Studies on physicochemical and microbiological parameters of water samples before and after jute retting. J. Biol. Sci., 11, 210-215(2011).

Das, S., B. Majumdar and A.R. Saha: Biodegradation of plant pectin and hemicelluloses with three novel Bacillus pumilus strains and their combined application for quality jute fibre production. Agric. Res., 4,354-364 (2015).

Das, S., B. Majumdar, A.R. Saha, S. Sarkar, S.K. Jha, S.K. Sarkar and R. Saha: Comparative study of conventional and improved retting of jute with microbial formulation. Proc. Natl. Acad. Sci. India Sect. B: Biol. Sci., 88, 1351-1357 (2018).

Datta, S., D. Saha, L. Chattopadhyay and B. Majumdar: Genome comparison identifies different Bacillus species in a bast fibreretting bacterial consortium and provides insights into pectin degrading genes. Sci. Rep., 10, 8169 (2020).

Di Candilo, M., P.M. Bonatti, C. Guidetti, B. Focher, C. Grippo, E. Tamburini and G. Mastromei: Effects of selected pectinolytic bacterial strains on water-retting of hemp and fibre properties. $J$. App. Microbiol., 108, 194-203 (2010).

Doi, R.H. and A. Kosugi: Cellulosomes: Plant-cell-wall-degrading enzyme complexes. Nat. Rev. Microbiol., 2, 541-551 (2004).

Donaghy, J.A., P.N. Levett and R.W. Haylock: Changes in microbial populations during anaerobic flax retting. J. Appl. Bacteriol., 69, 634-641 (1990).

Ge, J.P., H.Z. Ling, D. Zhao, G. Song and W.X. Ping: Screening of pectinase-producing strains and preliminary study on variation of bacteria population during flax degumming. J. Nat. Sci. Heilongjiang University, 24, 295-300 (2007).

Gomes, I., R.K. Saha, G. Mohiuddin and M.M. Hoq: Isolation and characterization of a cellulase free pectinolytic and hemicellulolytic thermophilic fungus. World J. Microbiol. Biotechnol., 8, 589-592 (1992)

Han, S.O., H.Y. Cho, H. Yukawa, M. Inui and R.H. Doi: Regulation and expression of cellulosomes and non-cellulosomal (hemi)cellulolytic enzymes in Clostridium cellulovorans during growth on different carbon sources. J. Bacteriol., 186, 4218-4227 (2004).

Kundu, A. and B. Majumdar: Optimization of the cellulase free xylanase production by immobilized Bacillus pumilus. Iranian J. Biotechnol., 16, 273-278 (2018).

Ling, H.Z., J.P. Ge, W. Wei and W.X. Ping: Analysis of bacterial community in water retting of flax. Chin. J. Appl. Environ. Biol., 15, 703-707 (2009).

Losonczi, A., E. Csiszar, G. Szakacs and L. Bezur: Role of EDTA chelating agent in bioscouring of cotton. Text. Res. J., 75, 411-417 (2005).

Majumdar, B., L. Chattopadhyay, S. Barai, A.R. Saha, S. Sarkar, S.K. Sarkar, S.P. Mazumdar, R. Saha and S.K. Jha: Impact of conventional retting of jute (Corchorus spp.) on the environmental quality of water: A case study. Environ. Monit.Assess., 191,440 (2019).

Majumdar, B., A.R. Saha, A.K. Ghorai, S.K. Sarkar, H. Chowdhury, D.K. Kundu and B.S. Mahapatra: Effect of fertilizer treatments on jute (Corchorus olitorius), microbial dynamics in its rhizosphere and residual fertility status of soil. Indian J. Agric. Sci., 84, 503-508 (2014b).

Majumdar, B., S. Sarkar, D. Biswas, A.R. Saha and S.K. Jha: Impact of field demonstrations of improved microbial jute retting technology using CRIJAF SONA. JAFNews, 12, 24-25(2014a).

Monisha, R., M.V. Uma and V.K. Murthy: Partial purification and characterization of Bacillus pumilus xylanase from soil source. Kat. Univ. J. Sci. Eng. Technol., 5, 137-148 (2009).

Munshi, T.K. and B.B. Chattoo: Bacterial population structure of the juteretting environment. Microb. Ecol., 56, 270-282 (2008).

Nedjma, M., N. Hoffmann and A. Belarbi: Selective and sensitive detection of pectin lyase activity using a colorimetric test: application to the screening of microorganisms possessing pectinlyase activity. Anal. Biochem., 291, 290-296 (2001).

Paice, M.G., R. Bermer and L. Jurasek: Viscosity enhancing bleaching of hardwood kreft pulp with xylanase from a cloned gene. Biotechnol. Bioeng., 32, 235-239 (1998).

Phutela, U., V. Dhuna, S. Sandhu and B.S. Chadha: Pectinase and polygalacturonase production by a thermophilic Aspergillus fumigatus isolated from decomposting orange peels. Braz. J. Microbiol., 36, 63-69 (2005).

Piccoli-Valle, R.H., I.V. Brandi, D.O. Silva and F.J.V. Passos: Pectin lyase production by Penicillium griseoroseum grown in sugar cane juice in repeated batch cultures. World J. Microbiol. Biotechnol., 17, 433-437(2001).

Roy, G. and S.C. Saha: An automatic integrated jute grading instrument. In: Proc. Int. J. Comp. Appl., pp 13-15(2013).

Roy, G., G.K. Bhattacharya, S. Sengupta and M. Mukherjee: A new electronic fibre bundle strength tester for jute. J. Inst. Eng. (India), 89, 10-13 (2009)

Saha, B.C.: Alpha-L-arabinofuranosidases: Biochemistry, molecular biology and application in biotechnology. Biotechnol. Adv., 18, 403$423(2000)$.

Soriano, M., P. Diaz and F.I.J. Pastor: Pectinolytic systems of two aerobic sporogenous bacterial strains with high activity on pectin. Curr. Microbiol., 50, 114-118(2005).

Tamburini, E.,A.G. León, B. Perito and G. Mastromei: Characterization of bacterial pectinolytic strains involved in the water retting process. Environ. Microbiol., 5, 730-736 (2003).

Yadav, S., P.K. Yadav, D. Yadav and K.D.S. Yadav: Pectin lyase:Areview. Process Biochem., 44, 1-10 (2009).

Yu, H. and C. Yu: Study on microbe retting of kenaf fiber. Enzyme Microb. Technol., 40, 1806-1809 (2007).

Zhang, J., G. Henriksson and G. Johansson: Polygalacturonase is the key component in enzymatic retting of flax. J. Biotechnol., 81, 8589 (2000). 